\title{
COVID-19 - rekomendacje dla alergologów i laryngologów
} COVID-19 - recommendations for allergists and ENT specialists

\author{
Bolesław Samoliński', Edyta Krzych-Fałta', Oksana Wojas', Adam J. Sybilski² \\ ${ }^{1}$ Zakład Profilaktyki Zagrożeń Środowiskowych i Alergologii, Wydział Nauk o Zdrowiu, \\ Warszawski Uniwersytet Medyczny \\ 2 II Klinika Pediatrii, Centrum Medyczne Kształcenia Podyplomowego w Warszawie
}

\begin{abstract}
Streszczenie:
Ostra choroba układu oddechowego COVID-19 ze względu na skalę zjawiska (pandemia) stanowi wyzwanie dla współczesnej medycyny i zdrowia publicznego. Tworzone rekomendacje (w różnych obszarach medycyny, w tym w alergologii) stanowią dla lekarzy i pracowników ochrony zdrowia wskazówki dotyczące właściwego postępowania w zaistniałej sytuacji epidemiologicznej.

Każdy pacjent z podejzzeniem infekcji koronawirusem musi mieć przeprowadzone badanie PCR w kierunku SARS-CoV-2 (wymaz z nosogardła). Szczyt wydzielania wirusa pojawia się od 3 do 5 dni. Należy pamiętać, że przebieg infekcji koronawirusowej najczęściej jest łagodny. U chorych z łagodnym przebiegiem zakażenia (bez cech zapalenia płuc), bez zaostrzenia choroby alergicznej, należy kontynuować leczenie choroby podstawowej i ściśle monitorować pacjenta. Zaleca się kontynuowanie leczenia przeciwzapalnego wziewnymi glikokortykosteroidami, ale powinny być one stosowane w postaci ciśnieniowych inhalatorów typu MDI lub inhalatorów proszkowych typu DPI. Eksperci zalecają udzielanie porad lekarskich tylko pacjentom wymagającym pilnej interwencji i podkreślają konieczność stosowania ochrony osobistej.
\end{abstract}

\section{Abstract:}

Coronavirus Disease 2019 (COVID-19) due to the scale of the phenomenon (pandemic) is a challenge to modern medicine and public health. Recommendations (in various areas of medicine, including allergology) provide physicians and health care professionals with instructions on how to properly deal with an epidemiological situation.

All patients with suspected coronavirus infection must have a SARS-CoV-2 PCR test (nasopharyngeal swab). The peak of virus release appears from 3 to 5 days. It should be remembered that the course of coronavirus infection is usually mild. In patients with a mild course of infection (no signs of pneumonia), without exacerbation of an allergic disease, treatment of the underlying disease should be continued, and the patient closely monitored. Glucocorticoids inhalation as an anti-inflammatory therapy should be continued, but they should be in the form of MDI pressure inhalers or DPI dry powder inhalers. Experts recommend giving medical advice only to patients who require urgent intervention and emphasize the use of personal protection.

Słowa kluczowe: koronawirus, pandemia, rekomendacje

Key words: coronavirus, pandemic, recommendations

stra choroba układu oddechowego (COVID-19) wywołana przez nowy koronawirus SARS-CoV-2, wcześniej znany jako 2019-nCoV, pojawiła się w Chinach w grudniu 2019 r. i rozprzestrze- nia się dynamicznie na całym świecie [1-4]. 11 marca 2020 r. Światowa Organizacja Zdrowia (WHO, World Health Organization) oficjalnie ogłosiła pandemię COVID-19, określając tę chorobę jako poważne za- 
grożenie dla zdrowia publicznego o zasięgu międzynarodowym. Obecnie choroba występuje na wszystkich kontynentach i we wszystkich krajach globu. Cały świat stanął do walki z nowym, nieznanym dotychczas zagrożeniem $[2,3]$.

Koronawirus został opisany po raz pierwszy w 1966 r. przez Tyrella i Bynoe, którzy wyodrębnili nowy gatunek wirusa $\mathrm{u}$ pacjentów $\mathrm{z}$ przeziębieniem [1]. Koronawirusy należą do podrodziny Coronaviridae, która została podzielona na cztery rodzaje: $\alpha, \beta, \delta$ oraz $\gamma$.

Koronawirusy mają osłonkę oraz pojedynczą nić RNA. Należą do tzw. dużych wirusów RNA, ponieważ mają genom w zakresie od 26,4 do 31,7 knt. Osłonki tych wirusów przypominają w obrazie mikroskopu elektronowego koronę słoneczną (corona) i stąd pochodzi ich nazwa. Koronawirusy są patogenami zwierząt i ludzi; te $z$ rodzaju $\alpha$ i $\beta$ przeważnie pochodzą od ssaków, najczęściej od nietoperzy, zaś te $z$ rodzaju $\delta$ i $\gamma$ - także od ptaków. Wśród siedmiu rodzajów koronawirusów powodujących zakażenia u ludzi $\beta$-koronawirusy mogą powodować infekcje o ciężkim przebiegu, zaś $\alpha$-koronawirusy zazwyczaj stanowią przyczynę infekcji o łagodnym przebiegu. Wirus SARS-Cov-2 wykazuje powinowactwo do białka receptorowego ACE-2 (enzymu konwertazy angiotensyny 2), które może być wykorzystane przez wirus do wnikania do komórek gospodarza. Kolejnym istotnym białkiem $\mathrm{w}$ patogenezie wydaje się seryna 2 (TMPRSS2) [1, 3, 4].

Pierwsze przypadki choroby spowodowanej nowym koronawirusem SARS-CoV-2 wystąpiły pod koniec 2019 r. w mieście Wuhan w Chinach. Niniejsze zachorowania udało się powiązać $\mathrm{z}$ targiem rybnym w tym mieście. Według tej teorii doszło wówczas do transmisji wirusa od nietoperzy. Główną manifestacją kliniczną pierwszych przypadków choroby w Chinach było zapalenie płuc o ciężkim przebiegu. Jednak dotychczasowe obserwacje wskazują, że choroba może mieć bardzo różny przebieg u poszczególnych chorych. Okres wylęgania wirusa przeciętnie wynosi $5 \mathrm{dni}$, lecz waha się w przedziale od 3 do 24 dni. Nieznany jest odsetek osób, które przechodzą chorobę całkowicie bezobjawowo. Objawy kliniczne najczęściej obejmują: kaszel, gorączkę, ból gardła, objawy nieżytu górnych dróg oddechowych oraz ogólne zmęczenie. Coraz więcej jest doniesień o objawach żołądkowo-jelitowych infekcji $[1,3,4]$. Ciekawe informacje dotyczą występowania jako pierwszych objawów infekcji zaburzeń węchu i smaku [2]. U części chorych rozwija się ciężkie zapalenie wirusowe płuc, wymagające intensywnego leczenia na oddziałach intensywnej opieki medycznej. Dane obserwacyjne pokazują, że choroba jest najbardziej niebezpieczna dla osób po 60. r.ż. i z chorobami przewlekłymi towarzyszącymi. Dane światowe z 13 lutego 2020 r. określają śmiertelność z powodu choroby na $2,2 \%$ [1].

W swojej pracy Dong X i wsp. na podstawie dokładnej analizy 11 przypadków klinicznych chorych $\mathrm{z}$ potwierdzoną infekcją SARS-CoV-2 opisali różne manifestacje kliniczne choroby COVID-19. Autorzy m.in. zauważają, że towarzyszące choroby alergiczne nie miały związku z cięższym przebiegiem choroby, zaś u pacjentów z POChP był on zdecydowanie cięższy [5].

\section{Postępowanie z pacjentami z chorobami alergicznymi w czasie pandemii COVID-19}

Każda osoba odwiedzająca poradnię może być źródłem zakażenia! Pacjent z alergią stanowi szczególny przypadek, gdyż ma objawy sugerujące COVID-19, a także - w razie gdy jest zakażony - $\mathrm{z}$ większą intensywnością rozsiewa wirus poprzez kichanie alergiczne.

Pierwszym krokiem w postępowaniu z pacjentem podejrzanym o zakażenie koronawirusem powinna być diagnostyka uwzględniająca różnicowanie. Diagnostykę należy rozpocząć od zebrania wywiadu (istnieje możliwość zebrania go telefonicznie). W szybkiej diagnostyce różnicowej pomocne mogą być odpowiedzi na kilka pytań (tab. 1). Zwróćmy uwagę, że alergicy mogą prezentować cechy alergii, szczególnie objawy histaminowe i kaszel, które z kolei mogą sugerować objawy COVID-19. Każdy pacjent z podejrzeniem infekcji koronawirusem musi mieć przeprowadzone badanie PCR w kierunku SARS-CoV-2 (wymaz z nosogardła). Szczyt wydzielania wirusa następuje od 3. do 5. dnia od wystąpienia objawów - to najlepszy czas na pobranie wymazów. Badania serologiczne mają tylko wartość pomocniczą i zawsze powinny być weryfikowane badaniem molekularnym [6].

Należy pamiętać, że przebieg infekcji koronawirusowej najczęściej jest łagodny, zwłaszcza u dzieci. Wiadomo, że chorzy na astmę lub POChP są w grupie ryzyka cięższego przebiegu infekcji COVID-19 i tę informację należy koniecznie przekazać pacjentowi. Inne schorzenia alergiczne (atopowe zapalenie skóry, alergie pokarmowe, alergie na leki lub owady błonkoskrzydłe) nie powodują zwiększonego ryzyka.

W diagnostyce bardzo pomocne mogą być badania obrazowe. Zwłaszcza badanie tomograficzne (TK) o wysokiej rozdzielczości ma ogromną wartość w diagnozowaniu, monitorowaniu oraz skuteczności leczenia. Nieliczne doniesienia wskazują, że 
Tabela 1. Diagnostyka różnicowa COVID-19 (na podstawie [6] w modyfikacji autorów).

\begin{tabular}{|c|c|c|c|c|}
\hline Objawy & Koronawirus (COVID-19) & Przezięhienie & Grypa & Alergia \\
\hline Czas trwania objawów & $7-25$ dni & do $14 \mathrm{dni}$ & $7-14 \mathrm{dni}$ & Kilka tygodni \\
\hline Kaszel & często (zwykle suchy) & często (łagodny) & często (zwykle suchy) & rzadko (zwykle suchy, w astmie częsty) \\
\hline Duszność & czasami & $n i e^{*}$ & nie $^{*}$ & $n \mathrm{ni}^{\star}$ \\
\hline Kichanie & nie & często & nie & często \\
\hline Wydzielina w nosie & rzadko & często & czasami & często \\
\hline Blokada nosa & czasami & często & czasami & często \\
\hline Utrata węchu & czasami & czasami & czasami & czasami \\
\hline Łzawienie & nie & nie & nie & często \\
\hline Ból gardła & czasami & często & czasami & czasami (najczęściej łagodny) \\
\hline Gorączka & często & krótki okres gorączki & często & nie \\
\hline $\begin{array}{l}\text { Uczucie zmęczenia lub } \\
\text { osłabienia }\end{array}$ & czasami & czasami & często & czasami \\
\hline Ból głowy & czasami & rzadko & często & czasami (ból w okolicy zatok przynosowych) \\
\hline Ból mięśni & czasami & często & często & nie \\
\hline Biegunka & Czasami & nie & czasami u dzieci & nie \\
\hline
\end{tabular}

* Jeżeli towarzyszy jej astma lub POChP, duszność może być nasilona. W przypadku COVID-19 duszność może się pojawić bez współwystępujących objawów astmy lub P0ChP.

również badanie USG przezklatkowe płuc może być pomocne [7].

Bez względu na wynik badania PCR (pacjent zakażony lub nie) należy kontynuować leczenie astmy lub innej choroby alergicznej. Nie ma doniesień, by leki stosowane $\mathrm{w}$ chorobach alergicznych (leki przeciwhistaminowe, glikokortykosteroidy [GKS], $\beta_{2}$-mimetyki etc.) miały jakikolwiek wpływ na zwiększenie ryzyka zachorowania na COVID-19 lub - jeśli dojdzie do zakażenia - by pogarszały przebieg choroby lub jej rokowanie [8].

$\mathrm{U}$ chorych z łagodnym przebiegiem zakażenia (bez cech zapalenia płuc), bez zaostrzenia choroby alergicznej należy kontynuować leczenie choroby podstawowej i ściśle monitorować pacjenta. Wydaje się, że leczenie profilaktyczne i wspomagające nie jest konieczne. W zaostrzeniach choroby alergicznej (np. ANN) należy zintensyfikować leczenie przeciwalergiczne zgodnie z przyjętymi zasadami. W sytuacji gdy jest nam znany dokładny wywiad i pacjent prezentuje częste zaostrzenia (np. o ciężkim przebiegu) astmy lub POChP, należy rozważyć podawanie azytromycyny $(1 \times 500 \mathrm{mg}$ przez $3 \mathrm{dni})$.

Według zaleceń Polskiego Towarzystwa Alergologicznego należy kontynuować leczenie przeciwzapalne wziewnymi GKS, ale powinny być one stosowane w postaci ciśnieniowych inhalatorów typu MDI (metered dose inhalers) lub inhalatorów proszkowych
(DPI, dry powder inhalers). Odradzane jest stosowanie leków w nebulizacji, ponieważ może ona spowodować zwiększoną aerolizację cząstek wirusa $\mathrm{w}$ otoczeniu i sprzyjać rozprzestrzenianiu się infekcji [9]. Nie ma jednoznacznych danych dotyczących stosowania GKS systemowych, jednak wydaje się zasadne kontynuowanie takiego leczenia u pacjentów, którzy tego wymagają. Podobnie wszystkie towarzystwa alergologiczne zalecają kontynuowanie immunoterapii podskórnej (z aeroalergenami i alergenami owadów błonkoskrzydłych) oraz leczenia biologicznego [9, 10]. Należy zwrócić jednak uwagę, że w czasie pandemii nie powinno się rozpoczynać immunoterapii alergenowej [10].

Wszyscy pacjenci z zakażeniem o przebiegu umiarkowanym i ciężkim powinni być hospitalizowani. W przypadku stwierdzenia objawów zapalenia płuc (u pacjentów z dodatnim i ujemnym wynikiem testu w kierunku obecności koronawirusa) należy zastosować azytromycynę doustnie $(1 \times 500 \mathrm{mg}$ przez $3 \mathrm{dni}$, a następnie $1 \times 250 \mathrm{mg}$ przez $4 \mathrm{dni}$ ). Antybiotyk powinien być podawany $\mathrm{w}$ skojarzeniu $\mathrm{z}$ chlorochiną (doustnie, zwykle $250 \mathrm{mg}$, w uzasadnionych przypadkach $500 \mathrm{mg}$ co $12 \mathrm{~h}$, przez $7-10 \mathrm{dni}$, jednak nie dłużej niż 10 dni). W czasie hospitalizacji obowiązuje ścisłe monitorowanie pacjenta (ocena lekarska kliniczna 2-3 razy dziennie i ocena parametrów życiowych: temperatura, ciśnienie tętnicze, tętno, liczba oddechów, ocena w skali Glasgow 2-3 razy dziennie oraz 
pulsoksymetria 2-3 razy dziennie; celem jest utrzymanie $\mathrm{SpO}_{2}>94 \%$ ).

\section{Zalecenia dla lekarzy zajmujących się pacjentami z chorobami alergicznymi}

W związku z szerzącą się pandemią COVID-19 Europejskie Towarzystwo Rynologiczne (European Rhinologic Society) opublikowało zalecenia dla rynologów. Autorzy tego dokumentu podkreślają istnienie wysokiego ryzyka zakażenia w grupie lekarzy otolaryngologów, ponieważ wirus rozprzestrzenia się głównie drogą kropelkową. Eksperci zalecają przyjmowanie w poradniach laryngologicznych jedynie pacjentów wymagających pilnej interwencji i podkreślają konieczność stosowania ochrony osobistej pod postacią masek chirurgicznych FFP2/N95, jednorazowych fartuchów ochronnych oraz stosowania ochrony oczu (tab. 2). Wszystkie konsultacje planowe i-zwłaszcza operacje powinny być odroczone. Kilka pomysłów na to, jak przygotować gabinet lekarski w czasie pandemii koronawirusa, przedstawia tabela 3. Konieczność zebrania wywiadu wstępnego przed wejściem na teren poradni zmniejsza ryzyko wpuszczenia do niej osoby z grupy wysokiego ryzyka zakażenia lub już zakażonej wirusem SARS-CoV-2.

Zwraca się szczególną uwagę na to, że u znacznej części pacjentów (20-60\%) obserwuje się utratę węchu. Ten objaw może wyprzedzać inne manifestacje kliniczne choroby [2].

\section{Podsumowanie}

Autorzy poruszają kwestię leków stosowanych przez pacjentów i zalecają ich regularne przyjmowanie. Odstawienie leków może zaś prowadzić do zaostrzenia objawów choroby podstawowej (alergicznego nieżytu nosa i przewlekłego zapalenia zatok przynosowych), co z kolei może maskować objawy COVID-19.

Tabela 2. Proponowane środki ochrony indywidualnej dla personelu medycznego niezbędne w opiece nad pacjentem z COVID-19.

- maseczka jednorazowego użytku z filtrem FFP2 lub FFP3 (z zastawką lub bez niej) (w przypadku braku półmasek FFP2/FFP3 zaleca się stosowanie zwykłych maseczek chirurgicznych)

- ochrona oczu - przyłbica, gogle lub okulary ochronne (także wielorazowego użytku, podlegają dezynfekcji)

- wodoodporny (wzmocniony) fartuch z długim rękawem (np. chirurgiczny), a w przypadku wykonywania procedur związanych z powstawaniem aerozolu/rozprysków - specjalistyczny kombinezon ochronny

- rękawiczki diagnostyczne jednorazowego użytku lateksowe lub nitrylowe, niejałowe (jałowe w procedurach aseptycznych) - dwie pary naraz

- czepek jednorazowy chirurgiczny

Tabela 3. Kilka porad, jak zadbać o bezpieczna praktykę lekarska (na podstawie [11] w modyfikacji autorów).

- Bądź na bieżąco z lokalną sytuacją dotyczącą COVID-19 i bądź przygotowany na podjęcie działań w twojej społeczności.

- Komunikuj się ze swoimi pracownikami i dbaj o ich bezpieczeństwo.

- Udostępnij informacje o tym, co obecnie wiadomo o wirusie, i o swoich planach gotowości

- Upewnij się, że masz pod ręką wystarczające środki ochrony osobistej.

- Upewnij się, że chory personel wie, że pozostanie w domu jest wskazane.

- Przygotuj swoje biuro do bezpiecznej segregacji i leczenia pacjentów z chorobami układu oddechowego.

- Przy wejściach i w innych strategicznych miejscach umieszczaj znaki z informacją o właściwej higienie dłoni i dróg oddechowych.

- Opracuj wytyczne/rekomendacje, które mogą być używane przez personel i zespół kliniczny, zwłaszcza w rozmowach przez telefon.

- Upewnij się, że dostępne są odpowiednie materiały sanitarne (służące do dezynfekcji rąk, chusteczki, pojemniki na odpady)

- Zastanów się nad zmianą aranżacji poczekalni w celu zachowania odstępów pomiędzy pacjentami (można np. ustanowić specjalny obszar tylko dla pacjentów z objawami oddechowymi).

- Rozważ alternatywy dla wizyt osobistych - rozmowy telefoniczne, informacje e-mailowe (np. skany badań).

- Podaj informacje na swojej stronie internetowej, portalu dla pacjentów lub poprzez bezpośrednie SMS-y dla pacjentów o tym, kiedy mają przyjść do gabinetu, a kiedy zostać w domu i monitorować objawy. 


\section{Piśmiennictwo}

1. Velavan TP, Meyer CG. The COVID-19 epidemic Trop Med Int Health. 2020; 25(3): 278-80.

2. https://www.rhinologyjournal.com (Access: 1.04.2020).

3. Guo YR, Cao QD, Hong ZS et al. The origin, transmission and clinical therapies on coronavirus disease 2019 (COVID-19) outbreak - an update on the status. Mil Med Res. 2020; 7(1): 11.

4. Lake MA. What we know so far: COVID-19 current clinical knowledge and research. Clin Med (Lond). 2020; 20(2): 124-7.

5. Dong X, Cao YY, Lu XX et al. Eleven Faces of Coronavirus Disease 2019. Allergy. 2020. http://doi.org/10.1111/all.14289. Online ahead of print.

6. https://www.cdc.gov/coronavirus/2019-ncov/symptoms-testing/symptoms.html (Access: 1.04.2020).

7. $X u X, Y u C, Q u J$ et al. Imaging and clinical features of patients with 2019 novel coronavirus SARS-CoV. Eur J Nucl Med Mol Imaging. 2020; 47(5): 1275-80.

8. https://acaai.org/news/during-COVID-19-pandemic-normal-allergy-and-asthma-medications-should-be-continued (Access: 1.04.2020).

9. Kowalski ML, Bartuzi Z, Bręborowicz A et al. Stanowisko grupy ekspertów Polskiego Towarzystwa Alergologicznego w sprawie postepowania u chorych na astme $i$ choroby alergiczne w okresie pandemii SARS-CoV-2.

10. Administration of subcutaneous allergen immunotherapy during the COVID-19 outbreak: A Work Group Report of the
AAAAI Immunotherapy, Allergen Standardization and Allergy Diagnostics (IASAD) Committee. https://education.aaaai.org/ immunotherapy_COVID-19.

11. https://education.aaaai.org/resources-for-a-i-clinicians/prepare-your-practice_COVID-19 (Access: 1.04.2020).

ORCID

A. Sybilski - ID - http://orcid.org/0000-0003-2389-277X

0. Wojas - ID - http://orcid.org/0000-0003-1653-9388

B. Samoliński - ID - http://orcid.org/0000-0002-4043-7747

E. Krzych-Fatta - ID - http:///orcid.org 0000-0002-9857-7136

Wkład autorów/Authors' contributions:

Wszyscy autorzy w równym stopniu przyczynili się do powstania artykutu.

Konflikt interesów/Conflict of interests:

Nie występuje.

Finansowanie/Financial support:

Nie występuje.

Etyka/Ethics:

Treści przedstawione w artykule są zgodne z zasadami Deklaracji Helsińskiej, dyrektywami

EU oraz ujednoliconymi wymaganiami dla czasopism biomedycznych.

Copyright: @ Medical Education sp. z 0.0. This is an Open Access article distributed under the terms of the Attribution-NonCommercial 4.0 International (CC BY-NC 4.0). License (https://creativecommons.org/licenses/by-nc/4.0/), allowing third parties to copy and redistribute the material in any medium or format and to remix, transform, and build upon the material, provided the original work is properly cited and states its license.

Adres do korespondencji:

prof. dr hab. n. med. Bolesław Samoliński

Zakład Profilaktyki Zagrożeń Środowiskowych

i Alergologii, Wydział Nauk o Zdrowiu,

Warszawski Uniwersytet Medyczny

02-097 Warszawa, ul. Banacha 1a 